\title{
Optimization of biogas fuel production from maize (Zea mays) bract waste: Comparative study of biogas production from blending maize bract with biogenic wastes

\author{
Uzodinma, E.O ${ }^{* 1}$, Ofoefule, A. $U^{1}$ and Enwere, N. $\mathrm{J}^{2}$ \\ *E-mail: uni_uzodinma@yahoo.com \\ ${ }^{1}$ Biomass Unit, National Center for Energy Research and Development, \\ ${ }^{2}$ Department of Food Science and Technology, University of Nigeria, Nsukka, Enugu State. \\ ABSTRACT
}

Biogas fuel production from blends of biological wastes such as pumpkin pod $(P), \operatorname{cow}(C)$ and swine(S) dung with maize bract (M) waste was understudied. The wastes were combined in the ratio of $M: P(1: 1), M: C(1: 1), M: S(1: 1)$ and $M: P: C(1: 1: 2)$ and charged separately into bioreactors of the same capacity (41.0L). Maize bract waste alone acted as the control. Its initial experimental study gave rise to the present investigation. The blends were thereafter subjected to anaerobic digestion batch process for 35 days on the prevailing atmospheric ambient temperature and pressure conditions. Results of the daily performances of each system showed that maize bracts alone had cumulative biogas yield of $59.0 \mathrm{~L} / \mathrm{Kg}$.T.S while those of blends (MP, MC, MS and MPC) were 72.0, 105.0, 150.50 and 113.20 L/Kg.T.S, respectively. The lag days (waiting period before flame production from each system) were also different; maize bracts alone -22 days, while MP, MC, MS and MPC were 13, 5, 25 and 3 days, respectively. Results also indicated increased biogas production from MS, MC and MPC systems. However, MS had lower quality biogas because of longest onset of flammable gas production (25 days). Comparison of volume of gas production from the blends with that of control using least significant differences (LSD) of means showed that gas yield was highly significant for MS,MPC and MC blends $(P<0.05)$. Again, analysis of biogas produced from the blends showed that MP contained $78.75 \%$ moist methane, $4.10 \% \mathrm{O}_{2}, 17.7 \% \mathrm{CO}_{2}, 0.04 \% \mathrm{NO}_{2}$ and $\mathrm{NO}_{x}, \mathrm{MC}-83.48 \%, 1.5 \% \mathrm{O}_{2}, 15.0 \% \mathrm{CO}_{2}, 0.01 \% \mathrm{NO}_{2}$ and NOx, MS- 81.96\% moist $\mathrm{CH}_{4}, 0.5 \% \mathrm{O}_{2}, 17.50 \% \mathrm{CO}_{2}, 0.02 \% \mathrm{NO}_{2}$ and $\mathrm{NO}_{\mathrm{x}}, \mathrm{MPC}-2.40 \% \mathrm{O}_{2}$, $20.40 \% \mathrm{CO}_{2}, 77.16 \%$ moist $\mathrm{CH}_{4}, 0.02 \% \mathrm{NO}_{2}$ and $\mathrm{NO}_{x}$. $\mathrm{CO}$ and $\mathrm{NO}$ were not found in all the blends during the analysis. Overall results indicated that the low flammable biogas from the maize bract waste could be enhanced significantly by blending with cow and swine dung.

Keywords: Biogas fuel production, biodegradable wastes, flammable gas production, mean volume of gas yield, renewable energy.

\section{INTRODUCTION}

Biogas is a cheap secondary renewable energy obtained from biomass through the process of anaerobic digestion. This gas which is a mixture produced by anaerobic bacteria (acidogens and methanogens) in the presence of little or no molecular oxygen, comprises $50-70 \%$ methane, 30$40 \%$ carbon dioxide and low amount of other gases (hydrogen, ammonia, water vapor, nitrogen, hydrogen sulfide, etc). However, the composition of the mixture depends on the source of biological waste and management of digestion process (Yadav and Hesse, 1981; Wantanee and Sureelak, 2004). Anaerobic bacteria act upon the biomass wastes and produce methane (bio methane) with other variable gases in the process of completing their life cycle under favourable condition. Methane within biogas gives it the ability to be used as fuel, the combustion of which releases energy. Biogas production has been developed as a result of waste management, agricultural production, cooking, electricity generation, correction of impact of negative effects of climate change and transportation amongst others. Abundant and readily available biodegradable wastes have been used as inputs for flammable biogas production in many places of the world (Anonymous, 1989; Energy Commission of Nigeria, 1998, Wantanee and Sureelak, 2004, etc.), in the form of blending, chemical and biological treatments, addition of metals at the required level, etc, and these in most cases resulted to improvement in the level of gas production. Biological materials have different biochemical characteristics. Hence, their gas productions potential vary. Blending under this process may involve addition of two or more biogenic wastes provided that the growth of bacteria during digestion is favoured. It has been seen as a very cheap method of optimizing biogas fuel production 
since the wastes are readily and abundantly available. Manures from human beings, animals and poultry are easily biodegradable and are rich in nitrogen than those of most plants. Raw plant materials are bound up in plant cells usually strengthened with cellulose and lignin, which are difficult to biodegrade. Therefore hydrolysis of lignocellulose materials from plants can be a major rate determining step in anaerobic digestion process (Kozo et al., 1996).Besides, the in balance ratio of carbon to nitrogen of majority of plant wastes/materials can limit the rate of organic waste conversion into methane (FAO/CMS,1996). Consequently, most suitable plant wastes for biogas production are those rich in biodegradable carbohydrate (sugars, starch), lipids and proteins and poor in hemi- cellulose and lignin (El-bassam, 1998). Animal wastes that have been utilized in biogas production include those of cow, swine, rabbit, horses, elephant, donkeys etc, because they are better biogas producers than plant wastes such as field grasses, spent grains, straws, peels, etc (Anonymous, 1989, Anonymous, 2009a, Ofoefule et al., 2010). Maize bract waste is obtained as a by product resulting from consumption of freshly harvested maize cobs during maturity and harvesting period. The bracts are thrown away as garbage along street dustbins. Reports on the utilization of maize bract in biogas production is not so common but has been used in feeding cows, as a dry forage material (Anonymous, 2009b). This paper therefore, carries report on comparative study of maize bract flammable gas yield from blending it with biogenic wastes such as pumpkin pod (P), cow ( C ) and swine (S) under definite proportions of MP (1:1) MC (1:1), MS (1:1) and MPC (1:1:2).

\section{MATERIALS AND METHODS}

Fresh maize bracts were collected from the street dustbin and left for two months before its digestion. Swine dung was obtained from Veterinary farm,
University of Nigeria, Nsukka; whereas cow dung was collected from a local market in Nsukka town. Fresh pumpkin pod was procured from a market dustbin at Opi in Nsukka. Fixed dome metallic prototype biodigesters were used and each has a working volume of 41.0 (figure 1). Materials such as top loading balance of $50 \mathrm{~kg}$ capacity ("Five, Goats") and model no. Z051599, trough, graduated white plastic bucket (liters), Pen-type thermo-hygrometer ( CE), Pocket- sized pH meter model 02895 A1 (Hanna Instruments), thermoplastic hose pipes, anemometer - An-4822, metallic beehive stand and biogas burner fabricated locally, were utilized.

Digestion Studies: Size-reduced (3 inches) dry maize bract wastes soaked for 7 days (Fulford, 1998) was differently batch digested with one of the bio reactors for 35 days followed by the degradation of the various blends (MS, MC, MP and MPC). The ratio of waste to water in each charging was 1:3 which was based on the moisture content of the organic wastes at the point of charging the bioreactors while the $\mathrm{pH}$ levels of the single wastes formed the basis for the blending. The waste to waste ratio were used as follows: M: C (1:1), M: S (1:1), M: $P(1: 1)$ and $M: P: C$ (1:1:2), (Srinivasan et al, 1997). The $M$ system that acted as the control was fermented anaerobically within the ambient temperature range of $23.5-38.0^{\circ} \mathrm{C}$ whereas the variants were later digested for the same retention time (35 days) at the prevailing ambient temperature range $\left(23.5-33.8^{\circ} \mathrm{C}\right)$ and pressure conditions of the atmosphere. Volume of gas production, ambient temperatures, relative humidity and wind speed, were monitored on daily basis while $\mathrm{pH}$ of each of the variant system was checked at two days intervals throughout the period of digestion. Flammability test was also carried out on daily basis until the system produced flammable biogas and occasionally till the end of digestion period.

\section{Fig 1: Biodigester}

\section{Analyses of the Wastes}

Physicochemical analysis: The physical and chemical compositions of the undigested wastes were determined before the digestion. Ash, moisture and fiber contents were carried out using AOAC method of 1990. Crude fat, nitrogen and protein contents were determined using Soxh let extraction and micro-Kjeldahl method described in Pearson (1976), respectively. Total carbohydrate and energy contents were obtained by use of methods in 
(Onwuka, 2005) while cellulose and lignin analyses were carried out using the methods of Crampton and Maynard (1938), Morrison (1972), respectively. Carbon content was done using Walkey and Black (1934) method while total and volatile solid contents were carried out using Meynell (1976) method.

Microbial analysis: The population of the microbes in each of the digester systems was determined at different times (At: charging, flammable, peak of production and end of digestion), during the period of study to monitor the growth of the microbes at the various stages. Modified Miles and Misra method described in Okore (2004) was used.

Data analysis: The data obtained from the volume of gas production for each of the systems was subjected to analysis using Microsoft Excel XP and Gen stat software package 7.22 DE, 2008.

Gas analysis: The flammable gas from the blended systems was analyzed using Unigas $3000^{+}$(E Instruments Group LLC).

\section{RESULTS AND DISCUSSION}

The results of the experimental study indicated that blending of maize bract waste with the other biogenic wastes (cow and swine dung, pumpkin pod) affected the total biogas fuel yield including the onset of flammable gas production with respect to synergy that existed between each blend. Daily biogas production, an index of digester performance, from the bracts and the various blends are displayed graphically in figure 2 . Biogas production from $\mathrm{M}-\mathrm{C}$ and MP-C commenced within $24 \mathrm{~h}$ of the experimental set-up while gas production commenced on the $2^{\text {nd }}$ day for M-S and M-P systems. Again, the production of flammable biogas took place at different waiting periods (lag days), (Table 2). The $\mathrm{M}$ system produced flammable gas on the $23^{\text {rd }}$ day of the digestion period with low mean gas biogas yield of $1.10 \mathrm{~L} / \mathrm{Kg}$.T.S /day. This may be as a result of high fiber and cellulose contents, low crude fat and protein contents and very low $\mathrm{pH}$ of undigested $\mathrm{M}$ (Table 1).Delay in $\mathrm{pH}$ changes pattern of $\mathrm{M}$ system at the initial stage of biodegradation may also have affected the onset of flammable gas production. The high fiber content indicates that $\mathrm{M}$ contains a lot of cellulose as shown on the table I, hemi-cellulose, pectin, lignin, plant wax etc. These structural polysaccharides are very difficult to biodegrade and can be a major rate determining step in anaerobic digestion process (Kozo et al., 1996). Moreover, the most suitable plant wastes for biogas production are those rich in biodegradable carbohydrates (sugars, starches), lipids and proteins but poor in hemi-cellulose, cellulose, lignin, pectin and plant wax (El-bassam, 1998). Besides, the effect of low $\mathrm{pH}$ on methanogenic bacteria has been confirmed by various research reports. The methanogenic bacteria which strictly survive in the absence of molecular oxygen are highly $\mathrm{pH}$ sensitive and survive optimally in the $\mathrm{pH}$ range of 6.5 to 7.5 and sometimes up to 8.5 (Anonymous, 1989; $\mathrm{FAO} / \mathrm{CMS}$, 1996). Again, the amount of carbon and nitrogen in the waste also effects the growth of the anaerobes. The carbon to nitrogen ( $\mathrm{C} / \mathrm{N}$ ratio) of undigested $M$ (Table 1 ) was above optimum range which has been given to fall within the range of 20 to 30: 1 (Kanu, 1988, Viswanath et al., 1992). The mean biogas yield for the blends (MC, MS, MP and MPC) is shown in Table 2. The onset of flammable gas production for the blends also varied. The M-C., $6^{\text {th }}$, $\mathrm{M}-\mathrm{P} ; 14^{\text {th }}$ and $\mathrm{M}-\mathrm{S} ; 26^{\text {th }}$ day, respectively. The mean biogas yield from M-S blend was highest but has longest waiting period for the flame production (25 days). This yield would have resulted from the adequate physicochemical properties of undigested blend such as total carbohydrates, crude protein, fat, volatile solid, $\mathrm{C} / \mathrm{N}$ ratio, etc., which are necessary for efficient biogas production (Table 1). However, its longest waiting period for flammable gas production could be as a result of $\mathrm{pH}$ pattern of changes (Table 6 ) during the experimental period. The slightly acidic range that operated for a longer time may have delayed the growth of methanogens. The mean gas yield was followed by that of MPC system (Table 2). Result showed shortest waiting period of 3 days amongst the blends. This may be due to fairly constant $\mathrm{pH}$ changes between neutrality and slightly alkaline condition within the period of gas production (Table 6) in addition to other favourable conditions discussed above. Again, feaces from cow, a rumen animal, would have created a favourable environment that aided faster growth of methane-producing bacteria and shortest onset of flammable gas production from the system. However, higher cumulative volume of gas may come from this system if the $\mathrm{C} / \mathrm{N}$ ratio of the undigested blend is within the optimum range (Table 1). The MC system also followed after MPC in high cumulative volume of flammable gas yield and shorter waiting period of 5 days (Table 2). This may be due to adequate physico-chemical properties of the undigested blend (ash, fat, $\mathrm{C} / \mathrm{N}$ ratio, volatile solids, $\mathrm{pH}$ etc). The undigested blend also had very low crude protein and total carbohydrate contents and these would have contributed to the extent of quantitative yield of gas from this blend. However, its quality gas production with that of MPC affirm the establishment of cow 
dung by other researchers as being superior in quality biogas production over other biodegradable wastes (Odeyemi, 1987). The MP system had mean gas yield of $2.06 / \mathrm{Kg}$.TS/day and a waiting period of 13 days (Table 2) which could have resulted from very high crude fiber content of the undigested blend and delay in low pH changes (Table 5) at the initial stages of the fermentation. The difference in means for volume of gas production from each of the Table 1: Physicochemical Properties of Undigested Pure Waste and the Blends blended systems was compared (Table 3) using least significant differences (LSD) at 5\% level. The result showed that volume of gas production was highly significant for MS, MC and MPC blends $(P<0.05)$. Table 4 shows the pattern of growth of the anaerobic microbes during the period of study while in Table 6; the results of analysis of flammable gas composition from the blends are shown.

\begin{tabular}{|l|l|l|l|l|l|l|l|l|}
\hline Parameters & M & P & C & S & MC & MS & MP & MPC \\
\hline Moisture (\%) & 5.6 & 10.50 & 22.62 & 38.05 & 37.95 & 6.40 & 9.15 & 38.85 \\
\hline Ash (\%) & 18.70 & 8.40 & 42.05 & 40.15 & 5.55 & 11.80 & 7.40 & 5.50 \\
\hline Crude fiber (\%) & 46.30 & 60.15 & 21.25 & 51.05 & 27.90 & 25.0 & 53.25 & 31.80 \\
\hline Crude fat (\%) & 0.40 & 1.50 & 0.45 & 0.10 & 1.0 & 1.06 & 0.60 & 1.50 \\
\hline Kjeldhal Nitrogen (\%) & 0.69 & 0.56 & 1.40 & 1.47 & 0.42 & 0.91 & 1.26 & 0.76 \\
\hline Crude protein (\%) & 4.34 & 3.50 & 8.75 & 9.19 & 2.63 & 5.68 & 7.89 & 4.73 \\
\hline Total solid (\%) & 94.40 & 89.50 & 77.38 & 61.95 & 62.05 & 93.60 & 90.85 & 61.55 \\
\hline Volatile solid (\%) & 93.99 & 81.10 & 35.33 & 7.14 & 56.50 & 81.80 & 87.85 & 33.55 \\
\hline Carbon (\%) & 26.45 & 35.45 & 26.87 & 15.25 & 26.66 & 20.85 & 41.66 & 35.27 \\
\hline C/N ratio (\%) & 38.09 & 78.73 & 20.20 & 16.37 & 23.78 & 27.23 & 26.27 & 46.41 \\
\hline Total carbohydrate (\%) & 70.96 & 76.10 & 26.13 & 12.51 & 24.97 & 65.46 & 74.96 & 49.82 \\
\hline Lignin (\%) & 0.31 & 0.75 & - & - & - & - & - & - \\
\hline Cellulose (\%) & 2.0 & 1.30 & - & - & - & - & - & - \\
\hline Energy (KJ/g) & 13.59 & 17.77 & 8.62 & 8.72 & 12.25 & 11.81 & 12.38 & 8.85 \\
\hline pH at charging & 4.87 & 5.70 & 8.11 & 7.60 & 8.0 & 8.20 & 6.20 & 7.80 \\
\hline
\end{tabular}

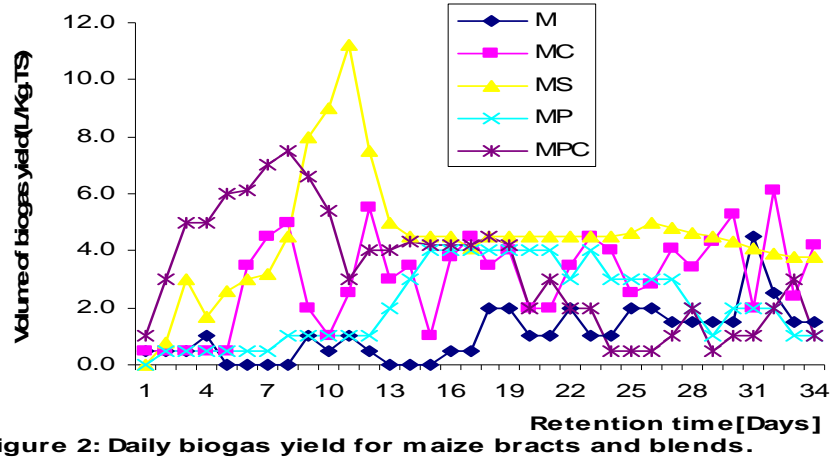

Table 2: Summary of Bio digester Performances during the Experimental Period

\begin{tabular}{|l|c|c|c|c|c|}
\hline Parameters & M (control) & MC & MS & MP & MPC \\
\hline Lag days & 22 & 5 & 25 & 13 & 3 \\
\hline Total gas yield (L/Kg.T.S) & 38.50 & 105.50 & 150.50 & 72.0 & 113.20 \\
\hline Mean gas yield (L/Kg.T.S/ day) & 1.10 & 3.00 & 4.47 & 2.06 & 3.23 \\
\hline Standard deviation (SD) & \pm 0.94 & \pm 1.58 & \pm 2.03 & \pm 1.38 & \pm 2.05 \\
\hline $\begin{array}{l}\text { Percentage gas yield with reference to } \\
\text { the highest yield (\%) }\end{array}$ & 25.58 & 69.77 & 100 & 47.84 & 75.22 \\
\hline
\end{tabular}


Am. J. Food. Nutr, 2011, 1(1): 1-6

Table 3: *Comparison of Means for Volume of Gas Production from Pure and Blended Wastes (Treatments) Using LSD

\section{Wastes}

Maize bracts (M)

MC

MP

MS

MPC

Mean

Least significant differences-LSD at $5 \%$ level.

Comparison is based on transformed means in parenthesis
Gas production (L/Kg.T.S/day)

1.1(1.2)

$3.0(1.8)$

$2.1(1.5)$

$4.4(2.2)$

$3.2(1.9)$

2.8(1.7)

0.22

Table 4: Total Number of Living Microbes in each System during the Digestion period (cfu/ml)

\begin{tabular}{|c|c|c|c|c|c|}
\hline Periods & M & MC & MS & MP & MPC \\
\hline Charging & $7.42 \times 10^{8}$ & $1.09 \times 10^{8}$ & $4.77 \times 10^{\prime}$ & $6.35 \times 10^{8}$ & $8.50 \times 10^{\prime}$ \\
\hline Flammable & $1.25 \times 10^{9}$ & $3.77 \times 10^{\prime}$ & $3.73 \times 10^{\prime}$ & $4.08 \times 10^{8}$ & $9.0 \times 10^{6}$ \\
\hline Peak of Production & $6.42 \times 10^{6}$ & $3.80 \times 10^{\prime}$ & $4.0 \times 10^{\prime}$ & $4.08 \times 10^{8}$ & $7.0 \times 10^{\prime}$ \\
\hline End of digestion period & $5.40 \times 10^{6}$ & $2.45 \times 10^{\prime}$ & $5.0 \times 10^{\prime}$ & $4.42 \times 10^{\prime}$ & $1.05 \times 10^{\prime}$ \\
\end{tabular}

Table 5: pH Changes at Two-day Interval during the Experimental Period for the Blends

\begin{tabular}{|l|c|c|c|c|}
\hline Days & MC & MS & MP & MPC \\
\hline 0 & 8.0 & 8.20 & 6.20 & 7.80 \\
\hline 2 & 8.1 & 6.70 & 6.40 & 7.50 \\
\hline 4 & 8.30 & 6.10 & 6.20 & 7.60 \\
\hline 6 & 7.70 & 6.0 & 6.20 & 7.80 \\
\hline 8 & 7.90 & 5.80 & 6.40 & 8.10 \\
\hline 10 & 7.30 & 6.0 & 6.40 & 7.70 \\
\hline 12 & 7.80 & 6.0 & 6.50 & 7.60 \\
\hline 14 & 7.80 & 6.0 & 6.60 & 8.0 \\
\hline 16 & 7.90 & 6.0 & 7.20 & 8.0 \\
\hline 18 & 8.30 & 6.10 & 7.70 & 8.0 \\
\hline 20 & 8.0 & 6.0 & 7.60 & 7.80 \\
\hline 22 & 7.90 & 6.20 & 7.60 & 7.90 \\
\hline 24 & 7.80 & 6.40 & 7.80 & 8.0 \\
\hline 26 & 8.0 & 7.50 & 8.0 & 8.10 \\
\hline 28 & 7.80 & 7.50 & 8.20 & 8.20 \\
\hline 30 & 7.90 & 7.70 & 8.0 & 8.0 \\
\hline 32 & 8.0 & 7.50 & 8.00 & 8.10 \\
\hline 34 & 8.10 & 7.50 & & \\
\hline
\end{tabular}

Table 6: Analysis of Component of Flammable Biogas from the Maize bract blends

\begin{tabular}{|c|c|c|c|c|c|c|c|}
\hline $\begin{array}{l}\text { Waste } \\
\text { blends }\end{array}$ & $\mathrm{O}_{2}(\%)$ & CO (\%) & $\mathrm{CO}_{2}(\%)$ & NO (\%) & $\mathrm{NO}_{2}(\%)$ & $\mathrm{NO}_{\mathrm{x}}(\%)$ & $\begin{array}{l}\text { Moist } \\
\mathrm{CH}_{4}(\%)\end{array}$ \\
\hline $\mathrm{MC}$ & 1.50 & 0.0 & 15.0 & 0.0 & 0.01 & 0.01 & 83.48 \\
\hline MS & 0.50 & 0.0 & 17.50 & 0.0 & 0.02 & 0.02 & 81.96 \\
\hline MP & 4.10 & 0.0 & 17.70 & 0.0 & 0.04 & 0.04 & 78.75 \\
\hline MPC & 2.40 & 0.0 & 20.40 & 0.0 & 0.02 & 0.02 & 77.16 \\
\hline
\end{tabular}




\section{CONCLUSION}

The result of this study has shown that biogas fuel yield from maize bract could be enhanced significantly by mixing it with cow, swine and pumpkin pod wastes. The maize bract- pumpkin-pod-cow blend gave the best result in onset of flammable gas production followed by maize bract-cow blend and then maize bract-pumpkin pod waste. However, maize-bract - swine blend produced highest cumulative volume of biogas fuel but had longest waiting period before flammable gas production. Overall results indicate that the low flammable biogas from maize bract waste could be enhanced significantly in the presence of cow, swine and pumpkin pod wastes. Never the less, addition of required chemicals to blends prior to digestion may lead to qualitative and quantitative biogas fuel yield from the blended wastes. Hence, maize bracts that are carelessly thrown away could be a cheap source of renewable energy for urban/rural dwellers by blending it with the dung of domestic animals that are commonly reared in the environment.

\section{REFERENCES}

Anonymous, (1989). A handbook of the Asian Pacific regional biogas research training center, Chengdu, China. Operating conditions of biogas fermentation, pp. 58-59.

Anonymous, (2009a). Biogas Technology in India: More than Ghandi's Dream? http://www.ganesha.co.uk/Articles/Biogas\%20Technol ogy\%20 India.htm. Accessed on 30-07-2009.

Anonymous, 2009-b www.haydryer.com /feeding regulation .pdf).

Anunputikul W, Rodtong S (2004). Laboratory scale experiment for biogas production from cassava tubers. "The Joint International Conference on Sustainable Energy and Environment (SEE)", 1-3 December, Hua Hin, Thailand, pp.238-243.

AOAC (1990). Official methods of analysis: Association of Analytical Chemists.14 ${ }^{\text {th }}$ Ed., USA, 22209.

Crampton E.W and L.A Maynard (1938). The relation of cellulose and lignin content to the nutritive value of animal feeds. Journal of nutrition 15: 383-395

El-bassam, N (1998). Energy plant species: their use and impact on environment, James \&James Ltd, London, pp. 321.

Energy Commission of Nigeria-ECN (1998). Rural renewable energy needs and live supply, pp. 40-42.

FAO/CMS (1996). A system approach to biogas technology; From "Biogas Technology a training manual for extension". A handbook, Intermediate technology publications, Southampton Row, London WCCB 4HH, UK, pp. 30-31.

Fulford, D. (1998). Running Biogas Programme. A handbook. 'How Biogas Works'. Intermediate Technology publication.103-05, Southampton Row, London. WCIB \$H, UK, pp.30-34.

Kanu, C. (1988). Studies on production of fuel solid waste. Nig. J. Bio Tech. 6:90-96.

Kozo I, Hisajima S, Darryl R.J. (1996). Utilization of agricultural wastes for biogas production in Indonesia. In: traditional technology for environmental conservation and sustainable development in Asia pacific Region, 9th ed. Pp, 134-138.

Meynell, P. J (1976) Methane. Planning a digester. Prison Stable Court. Clarington, Dorset. Sochen Books, pp.3.

Morrison, I.M (1972). A semi-micro method for the determination of lignin and its predicting the digestibility of forage crops. Journal of Science-FoodAgriculture, 23:455-463.

Odeyemi, O. (1987). Research needs priorities and challenges in biogas production and technology in Nigeria. In: Seminar Proceedings at the National Centre for Genetic resources and Biotechnology, Ibadan, Nigeria, 1987.

Ofoefule, A.U., E.O. Uzodinma and C.N. Anyanwu (2010). Studies on the effect of anaerobic digestion on microbial flora of animal wastes 2: Digestion and modeling of process parameters. Trends in Applied Sciences Research 5 (1): 39-47.

Okore, V.C. (2004). A standard laboratory Technique in Pharmaceutics and Pharmaceutical Microbiology (2nd edition). El'Demark Publishers, Nigeria, pp. 24-26.

Onwuka, G.I (2005). Food Analysis and Instrumentation (theory and practice). Naphtali prints, Nigeria, pp.89, $95-96$.

Pearson, D. (1976). The Chemical Analysis of Food $.7^{\text {TH }}$ Edition Churchill Livingstone. New York, pp. 11-14-15.

Srinivasan S.V, Jayanthis S, Sundarajan R. (1997). Synergistic effect of kitchen refuse and domestic sewage in biogas production. Niational Seminar on anaerobic technologies for waste water treatment. Madras (India) pp 87-91.

Viswanath P, Devi, SS and Nand, K (1992). Anaerobic digestion of fruit and vegetable processing wastes for biogas production, Bioresource Technology, 40: 43-48.

Walkey, A. and Black, L.A. (1934). An examination of the Degtjareff method for determining soil organic matter and proposed chromic acid titration method. J. Soil Science, 37:29-38.

Yadava, L.S. and P.R. Hesse (1981). The development and use of biogas technology in rural areas of Asia (A status report 1981). Improving soil fertility through organic recycling, FAO/UNDP Regional Project RAS/75 004, Project field Document No. 10. 